\title{
Length-weight relationship and condition factor of Pethia ticto (Hamilton, 1822) from Gomti river in Sultanpur, Uttar Pradesh
}

\author{
Ashish Kumar Maurya ${ }^{1}$, Laxmi Prasad ${ }^{1 *}$ and Ravi Kumar ${ }^{2}$ \\ ${ }^{1}$ Narendra Deva University of Agri. \& Tech. Kumarganj, Faizabad- 224229 (U.P.), INDIA \\ ${ }^{2}$ ICAR-National Research Centre on Integrated Farming, Piprakothi, Motihari (E. Champaran)-845429, INDIA \\ *Corresponding author. E-mail: vermalp@yahoo.com \\ Received: November 22, 2017; Revised received: December 26, 2017; Accepted: February 25, 2018
}

\begin{abstract}
This study describes the length-weight relation (LWR) of small indigenous fish Pethia ticto from Gomti River, Aamghat, Haliyapur, Sultanpur district $26^{\circ} 29 \mathrm{~N}$ and $81^{\circ} 44 \mathrm{E}, 751 \mathrm{~m}$ (msl) Uttar Pradesh, India. A total of 306 specimens were caught by random sampling method using traditional fishing gear as gillnet, cast net and dragnet of various mesh sizes from June 2016 to May 2017, once in a month. Total Length $(\mathrm{mm})$ was measured from anteriormost part of the snout to the posterior-most part of the caudal fin and body weight $(\mathrm{g})$ were taken by digital electronic balance. The analysis of data shows that the allometric coefficient is close to isometric value (3.0). Allometric growth indicates a more rotund population of fish when the values of growth coefficient are higher than $3.0(\mathrm{~b}>3)$. If the value of growth coefficient is less than 3.0, the population of fish is known to be less rotund. Isometric growth indicates that the shape of fish does not change as it grows $(b=3)$. The coefficient of determination $\left(R^{2}\right)$ was also found significant $(=0.97)$. Fulton's condition factor further supports the results obtained ranged from 1.041 to 1.660 shows the degree of well being of a fish. This study is helpful in providing relevant information in the assessment of stock and estimation of the fish condition about its environment.
\end{abstract}

Keywords: Coefficient of determination, Fulton's condition factor, Gomti River, Length-weight relationship, Pethiaticto.

\section{INTRODUCTION}

Fisheries management and research often require the use of biometric relationship to transform data collected in the field into appropriate indices as the lengthweight relationship, condition factor, growth rate estimation, estimation of population characteristics and stock assessment (Ecoutin and Albaret, 2003). LWR of fishes is important in fisheries and fish biology because they allow the estimation of the average weight of the fish of a given length group by establishing a mathematical relation between them (Mir et al., 2012). LWR can also be used in setting yield equation for estimating the number of fish landed and compared the population in space and time (Singh et al., 2011). It is an essential tool for getting knowledge on the increment in weight as a function of length in that way monitoring the healthiness of the fish species under study (Le Cren, 1951; King, 1996; Sinorice al., 2004). The morphometric relationships between length and weight can be used to assess the well-being of individuals and to determine possible differences between separate unit stocks of the same species (King, 2007). In addition, length-length relationships are also important in fisheries management for comparative growth studies (Moutopoulos and Stergiou, 2002).
Fulton's condition factor $(\mathrm{K})$ is also widely used in fisheries and fish biology to study the condition of a fish by calculating the relationship between the length and its weight (Froese, 2006). The different values in $\mathrm{K}$ of a fish also indicate the state of the degree of food availability in its habitat (Anibeze, 2000). To best of knowledge, scarce information is available on the length-weight relationship of $P$. ticto from Gomti river. The present work aims to carryout LWR of P.ticto from a specific stretch of Gomti River.

\section{MATERIALS AND METHODS}

Sample collection: The Gomti River is tributary of river Ganga and a perennial river of Awadh plains running across the significant part of U.P. covering nine districts and $940 \mathrm{Km}$ stretch area. The samples of $P$. ticto used in the present study were collected during daytime on a seasonal basis from Haliyapur, District Sultanpur, Uttar Pradesh, India from June 2016 to May 2017.The various fishing gears such as cast net, gill net and dragnet were used for collecting fish specimens. After collection, specimens were preserved in $10 \%$ formalin solution and were correctly labelled. The fish specimens were identified according to Jayaram, (1981) and Talwar and Jhingran, (1991). The total length (TL) of each fish was taken from the tip of the 
snout to the extended tip of the caudal fin by measuring the scale and weighed to the nearest $0.01 \mathrm{~g}$ (Total weight) by a digital weighing machine (SONAR).

Length-weight relationship: The weight-length relationship of $P$. ticto were calculated using the expression: $\mathrm{W}=\mathrm{a} \mathrm{L}^{\mathrm{b}}$, where the $\mathrm{W}$ is the body weight $(\mathrm{g}), \mathrm{L}$ the total length (mm), "a" is intercept and b is the regression coefficient (slope). Parameters a and b of the weight-length relationship were estimated by Le Cren's formulae (1951): $\log W=\log a+b \log L$, where, $\mathrm{W}=$ weight of fish in $\mathrm{gm}, \mathrm{L}=$ length of fish in $\mathrm{mm}$, where "a" and " $\mathrm{b}$ " are intercept and regression coefficient respectively. The determination coefficient $\left(\mathrm{R}^{2}\right)$ was used as an indicator of the quality of the linear regressions. Additionally, 95\% confidence limits of the parameters "a" and " $b$ " and the statistical significance level of $\mathrm{R}^{2}$ were estimated. In order to confirm whether $b$ values obtained in the linear regressions were significantly different from the isometric value of $\pm 95 \%$ was applied. All the statistical analyses were considered significance level of $5 \%(\mathrm{P}<0.05)$.

Condition factor (K): The condition factor which shows relative fatness and well being of fish is determined by Fulton's formulae (Freose, 2006): $\mathrm{K}=100$ * $\mathrm{W} / \mathrm{L}^{3}$, where $\mathrm{W}=$ weight $(\mathrm{g}), 1=$ length $(\mathrm{mm})$ and 100 is a factor to bring the value of $\mathrm{K}$ near unity.

\section{RESULTS AND DISCUSSION}

A total of 306 specimens ranging from 37-93mm TL (Total length) and 0.82-12.47 gm BW (body weight) were used for the study of length-weight relationship and condition factor.The length-weight relationship was calculated as $\log \mathrm{W}=-5.076+3.115 \mathrm{Log} \mathrm{L}$, with $\mathrm{R}^{2}=0.97$. The weight of the fish increases logarithmically with an increase in length and with the value of "b" lying between 2.5 and 3.5 but usually close to 3.0 (Carlander, 1969). The b value was calculated to find out whether the fish is growing allometrically or isometrically. If the "b" value is 3.0 the growth is considered to be isometric, and it indicates that the length and weight of fish are in ideal proportion. If " $b$ " value is less than 3.0 (less rotund) or greater than 3.0 (more rotund), it indicates allometric growth of fish (Ricker,

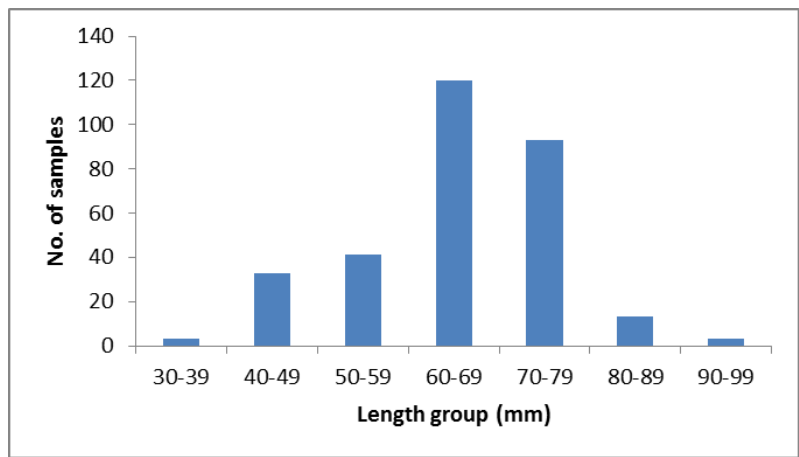

Fig. 1. Number of fish samples in each length group of P. ticto.

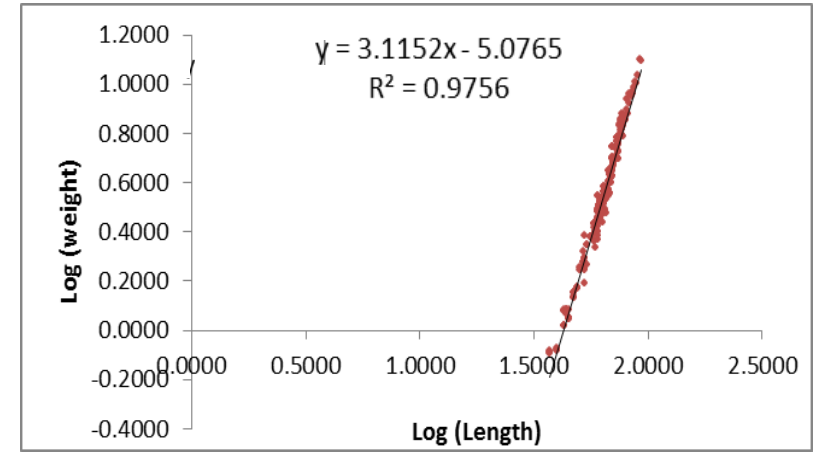

Fig. 2. Length weight relationship of $P$. ticto.

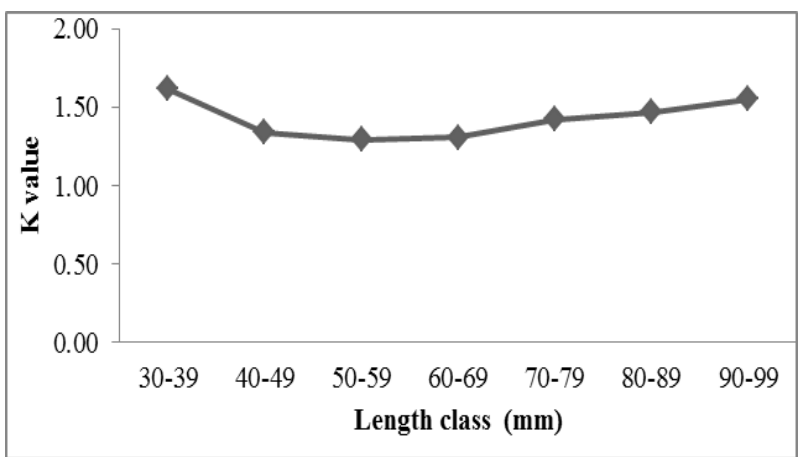

Fig. 3. Fulton's condition factor for each length group of P. ticto.

1958 and Tesch, 1968). Exponential value " $b$ " of the length-weight relationship normally falls between 2.5 and 4.0 (Hile 1936, Martin 1949). In the present study the "b" value obtained is 3.115 , so we can conclude that a positive allometric growth has been observed. Regarding growth type, a value close to 3.0 follows the cube law indicating that the fish grows isometrically and values other than 3.0 indicate allometric growth (Bagenal and Tesch,1978). Hossain (2010) also reported similar results $(b=3.093)$ for Pethiaticto $\mathrm{s}$ from Padma River in northwestern Bangladesh. Muhammad et al. (2016) found the "b" value as 4.10 from Indus River in Pakistan showing positive allometric growth also found similar to our results in Pethia ticto. Alam et al. (2014) found the "b" value for candidate species as 3.10 from Pagla River of Bangladesh which is almost similar to our result. The b value obtained by Sarkar et al. (2013) from Ganga River was 2.59 for Pethia ticto showing a negative allometric growth. Similar to our study the value of " $b$ " were observed to be more than 3.0 in Indian major carp Cirrhinus mrigala (Dwivedi et al.,2017). Difference in b values can be attributed to the combination of one or more factors such as: number of specimens examined; area; seasonal effect; habitat; degree of stomach fullness; gonadal maturity; sex; health and general fish condition; preservation technique; and differences in the observed length ranges of the specimens caught (Wootten, 1998). The coefficient of determination was found to be the 0.97 indicating highly significant value of the result. 
In the present study, the Fulton's condition factor ranged from 1.0411 to 1.6603 with an average value of 1.35. The Fulton's condition factor for length group 30 $-39 \mathrm{~mm}, 40-49 \mathrm{~mm}$ and $50-59 \mathrm{~mm}$ was found to be as $1.62,1.34$ and 1.29 respectively. The Fulton's condition factor is an index of well being or condition of fish measured by the unit called condition factor $(\mathrm{K})$. In the present study, the condition factor analysis has resulted in $\mathrm{K}$ value more than 1 in each length group. Hence, it can be concluded that the fitness of the candidate fish species is good in the ecosystem. This also indicates a sign of good health status of fish as well as its habitat.

The condition factor was found to be comparatively less for middle length groups (40-49 to $70-79 \mathrm{~mm}$ ) when compared to initial and final length groups. The similar result for $P$. ticto has been reported by Sarkar et al. (2013) as 1.2 from Ganga River. Muhammad et al. (2016) found ' $\mathrm{K}$ ' value as 1.58 for $P$. ticto from Indus River during their study. Alam et al. (2014) also found the $\mathrm{K}$ value as 1.36 which is again similar to our results. The factors affecting the $\mathrm{K}$ value includes sex, size, season and degree of gonadal development in fish (Heincke, 1908). Ecological factors, food supply and parasitism, have a significant influence on the well being of the fish (Le Cren, 1951).This study indicates that $P$. ticto population is naturally being recruited in the study area. The samples observed are also healthy as indicated by the length and its weight relationship. Further studies are needed to assess the abundance of other fish stock available in relation to their environment to maintain the preferred habitat.

\section{Conclusion}

To best of our knowledge, there has been very little or no previous information dealing with the LWR of P.ticto in Gomti River, India. The present LWR study for P.ticto will, therefore, provide useful information for fishery biologists and conservation agencies for sustainable fishery management.

\section{ACKNOWLEDGEMENTS}

The authors are thankful to the local fish farmers for help during the study. First Author is also thankful to the Hon'ble Vice Chancellor NDUAT, Kumarganj, Faizabad for facilitating and appreciating the present work.

\section{REFERENCES}

Alam, M.M., Rahman, M.T. and Parween, S. (2014). Morphometric characters and condition factors of five freshwater fishes from Pagla river of Bangladesh. International Journal of Aquatic Biology.2(1): 14-19.

Anibeze, C.I.P. (2000). Length-weight relationship and relative condition of Heterobranchus longifilis (Valencienness) from Idodo River. Nigeria. Naga, International Centre for Living Aquatic Resources Manage- ment Quarterly.23 : 34-35.

Bagenal, T. B. and Tesch, F. W. (1978). Age and growth, In:Methods for assessment of fish production in fresh waters, edited by T.B. Baegnal, IBP Hand book No.3, Third edition. London: Blackwell Scientific Publication, pp. 101-136.

Carlander, K.(1969). Hand book of freshwater fishery biology. Jowa State University Press, Ames, pp 752.

Dwivedi, A. K., Sarkar, U. K., Mir, J. I., Tamot, P. and Vyas, V. ( 2017). Comparative length- weight relationship, condition and form factor of Indian Major Carp, Cirrhinus mrigala in the Ganges basin, India. Journal of the Kalash Science, 5(1):1-7.

Ecoutin, J.M. and Albaret,J. J. (2003). Length-weight relationship of 52 fish species from West African estuaries and lagoons. Cybium.27 : 3-9.

Froese. R. (2006). Cube law, condition factor and weightlength relationships: History, meta-analysis and recommendations. Journal of Appllied Ichthyology.22 : 241253.

Hile, R.(1936). Age and growth of the Cisco, Leucichthus arbedi (Lesuer), in lakes of the northeastern highlands, Wisconsin, U.S. Bureau of Fisheries Bulletin. 19: 211317.

Heincke, F. (1908). Berichtu"ber die Untersuchungen der Biologischen Anstalt auf Helgoland zurNaturgeschichte der Nutzfische. (1. April 1905 bis 1. Oktober 1907). In: Die Beteiligung Deutschlands an der Internationalen Meeresforschung, 4. \& 5. Jahresbericht. Verlag von Otto Salle, Berlin, pp. 67-150.

Hossain, M.Y.(2010). Morphometric Relationships of Length-Weight and Length-Length of Four Cyprinid Small Indigenous Fish Species from the Padma River (NW Bangladesh). Turkish Journal of Fisheries and Aquatic Sciences 10: 131-134.

Jayaram, K.C. (1981) The freshwater fishes of the Indian region. Narendra Publishing House, New Delhi, pp 551.

King, M. (2007). Fisheries biology, assessment and management. Second Edition. Blackwell Scientific Publications, Oxford.

King, R.P.(1996). Length-weight relationship of Nigeria freshwater fishes. Naga International Centre for Living Aquatic Resources Management Quaterly.19(3): 49-52.

Le Cren, E.D.(1951). The length-weight relationship and seasonal cycle in gonad weight and condition in the perch (Perca fluviatilis). Journal of Animal Ecology.20: 201- 219

Martin, W. R. (1949). The mechanics of environmental control of body form in fishes, University of Toronto studies, Biological series 58, Ontario Fisheries Research Laboratory, vol. 70, pp 1-91.

Mir, J.I., Sarkar, U.K.,Dwivedi, A.K.,Gusain, O.P.,Pal A. and Jena, J.K. (2012). Pattern of intrabasin variation in condition factor, relative condition factor and form factor of an Indian Major Carp, Labeo rohita (HamiltonBuchanan, 1822) in the Ganges Basin, India. European Journal of Biological Sciences. 4 : 126-135.

Moutopoulos, D.K. and Stergiou, K.I. (2002). Length-weight and length-length relationships of fish species from Aegean Sea (Greece). Journal of Applied Ichthyology. 18: 200-203.

Muhammad, H., Iqbal, Z. and Akhlaq T. (2016). Lengthweight, length-length relationships and condition factor 
of fishes of family cyprindae from the Indus River, Pakistan. Punjab University Journal of Zoology. 31(2): 143-147.

Ricker, W.E.(1958). Hand book of computations for biological statistics of fish populations. Bull. Fish. Res. Bd, Canada, 119, pp 300.

Sarkar, U.K., Khan, G.E., Dabas, A., Pathak, A.K., Mir, J.I., Rebello, S.C., Pal A. and Singh S.P.(2013). Length weight relationship and condition factor of selected freshwater fish species found in River Ganga, Gomti and Rapti, India. Journal of environmental biology.34: 951-956.

Singh, N.O., SarmaD. and Singh,N.G. (2011). Lengthweight relationship of Tor putitora (Hamilton) from
Kosi River Uttarakhand considering different stages of its lifespan. Indian Journal of Fisheries. $58: 35-38$.

Sinovcic, G., Franicevic, M., Zorica, B. and Ciles-Kec, V. (2004). Length-weight and length-length relationships for 10 pelagic fish species from the Adriatic Sea (Crotia). Journal of Applied Ichthyology, 20: 156-158.

Talwar P.K and Jhingran V.G.(1991). Inland Fishes of India and adjacent countries. Vol.II,. Oxford and IBH Publishing Company. Limited, Janpath, New Delhi, pp 543-1158.

Tesch, F.W. (1968). Age and Growth. In: methods for the assessment of fish production in freshwater. (ed. W. R. Ricker), IBP Handbook, No. 3, pp 98-130.

Wootton, R.J. (1998). Ecology of teleost fishes, Netherlands, $2^{\text {nd }}$ Edition, kluwer Academic Publishers. 